\title{
PERAN PENDIDIKAN PANCASILA DAN KEWARGANEGARAAN MEMBANGUN KARAKTER GENERASI PINTAR
}

\author{
Dinda Finka Listiowati ${ }^{1}$, Anita Trisiana ${ }^{2}$ \\ Universitas Slamet Riyadi Surakarta \\ dindafinka2@gmail.com
}

\begin{abstract}
ABSTRAK
Penelitian ini dilakukan untuk membentuk karakter generasi cerdas melalui pembelajaran pendidikan pancasila dan kewarganegaraan. Penelitian ini menggunakan pendekatan metode deskriptif. Data yang diperoleh melalui pengamatan, wawancara, kajian pustaka dan dokumentasi. Kajian ini mengkaji upaya yang telah dilakukan guru pendidikan Pancasila dan kewarganegaraan dalam membentuk karakter generasi muda yang pintar, peran dan kendala positifnya. Dari penelitian ini ditemukan bahwa generasi penerus mampu menunjukkan kemampuan berpikir kritis dan menunjukkan perilaku karakter dalam lingkungan.
\end{abstract}

Kata Kunci: Membangun Karakter, Generasi Pintar

\begin{abstract}
This research was conducted to form the character of the intelligent generation through learning Pancasila and citizenship education. This study uses a descriptive method approach. Data obtained through observation, interviews, literature review and documentation. This study examines the efforts that have been made by Pancasila and citizenship education teachers in shaping the character of the smart young generation, their roles and positive constraints. From this research, it was found that future generations were able to show critical thinking skills and show character behavior in the environment.
\end{abstract}

Keywords: Character Building, Smart Generation 


\section{PENDAHULUAN}

Indonesia adalah negara yang sedang berkembang yang sangat ingin mewujudkan misinya menjadi negara maju, dan dihargai serta dikagumi oleh negara lain di dunia. Effendie (2012) mengemukakan bahwa perwujudan cita-cita bangsa harus mempersiapkan masyarakat dengan pendidikan dan karakter yang baik.

Dalam Pembukaan UUD 1945, bangsa Indonesia memandang pendidikan sebagai rencana paling awal pendirian regional, "mencerdaskan kehidupan bangsa". Pasal tiga undang-undang Nomor 20 Tahun 2003 membahas Sistem Pendidikan Nasional menegaskan bahwasannya peran pendidikan nasional adalah meningkatkan kemampuan serta membangun karakter dan untuk mencapai perkembangan kebudayaan. Kearifan manusia harus didasarkan pada kemampuan atau karakter peradaban yang bermartabat. Maka dari itu, pendidikan harus dimanfaatkan buat mewujudkan kemampuan dan pembinaan karakter yang dibutuhkan oleh fungsi pendidikan nasional sebagai halnya diatur Pasal tiga Undang-Undang Nomor 20 Tahun 2003, karena dengan demikian akan menuntun masyarakat Indonesia untuk lebih memikirkan pembangunan dan kemajuan bangsa.

Di setiap jenjang pendidikan, semua guru memiliki tanggung jawab untuk menjadi teladan bagi generasi yang lebih cerdas. Agar tercipta generasi muda yang baik sesuai dengan tujuan pendidikan pancasila keseluruhan, pengajar berupaya membentuk generasi muda yang pintar agar senantiasa berpegang terhadap kriteria yang tersimpul pada ajaran Pancasila.

Kepintaran adalah fitur khusus setiap orang, memungkinkan mereka untuk memahami semua masalah dalam kehidupan sehari-hari secara mendalam. Mengenai kecerdasan, Gardner (Amstrong, 2002) mengartikan kecerdasan sebagai kemampuan untuk menyelesaikan hambatan, kesanggupan mengajukan hambatan terkini untuk dipecahkan, serta keterampilan pembuatan sesuatu dan memberikan layanan yang bermanfaat terhadap sosial budaya. Prayitno (2010) mengemukakan bahwa kecerdasan adalah kemampuan untuk memanipulasi elemen kondisional yang agar sukses sampai tujuan

Apabila semua bakat generasi penerus dimaksimalkan, kecerdasan seseorang dapat berkembang dengan baik. Cara pertama untuk menguraikan kepintaran adalah dengan mempertajam keterampilan berpikir kritis. Edward Glaser menjelaskan berpikir kritis adalah: 1) sikap yang ingin berpikir mengenai hambatan masa depan; 2) pengetahuan, keingintahuan dan penalaran logis; 3) menerapkan ini Kemampuan / keterampilan metode.

Kepribadian generasi pintar melahirkan generasi yang semangat berdasarkan kepribadian identitas dirinya dan menghargai kepribadian serta identitas diri orang lain. Kala nanti negara adalah milik generasi muda, oleh sebabnya jika generasi yang lebih tua mempersiapkan generasi yang akan datang agar karakternya lebih pintar dari generasi sebelumnya, maka suatu negara akan maju. Tanpa persatuan dan solidaritas yang aktif dan hidup bersama, mustahil bagi manusia untuk mengatasi penderitaan dalam hidup. Jika persatuan dan kesatuan tidak diorganisir dengan baik dan bijaksana, tidak ada gunanya. Karakter adalah cara seseorang berpikir atau berperilaku dalam kehidupan sehari-hari, yang merupakan ciri setiap orang yang bernyawa dan kerja keras bersama di konteks keluarga, komunitas, bangsa atau negara. Menghadapi seseorang dengan karakter baik bukan tanpa hambatan, namun individu tersebut harus mampu mengambil keputusan dan siap bertanggung jawab atas segala dampak dari pertimbangan yang telah ditata.

Pembangunan karakter adalah salah satu sasaran untuk mewujudkankan kesanggupan generasi selanjutnya yang mempunyai kepintaran, individualitas, dan tingkah laku, sehingga generasi penerus tumbuh dan berkembang dengan karakter yang berakhlak mulia yang memiliki nilainilai kebangsaan dan agama yang luhur.

\section{METODE}

Metode yang saya gunakan dalam memecahkan masalah ini yaitu memakai cara 
pengumpulan informasi yang bersumber dari internet. Penyusunan jurnal ini saya menyusun sedemikian rupa dengan searching pada internet secara bertahap.

\section{PEMBAHASAN}

Undang undang Nomor dua puluh Tahun 2003 tentang Sistem Pendidikan Nasional memuat jaminan nasional pendidikan karakter bagi generasi muda Pasal 3 menjelaskan: "Peran pendidikan nasional adalah membentuk dan mengembangkan keterampilan progresif nasional yang bermartabat untuk mencerdaskan kehidupan dan tujuan bangsa. Yaitu untuk menumbuhkan kemampuan. Agar menjadi pemuda yang beriman dan beriman kepada Tuhan Yang Maha Esa, berakhlak mulia, berilmu, dan mampu menciptakan hal-hal baru, mandiri dan menjadi warga negara dengan prioritas yang sama dalam hak, kewajiban, dan tanggung jawab. "

Peran pancasila dan kewarganegaraan yaitu menumbuhkembangkan masyarakat negara agar bermanfaat untuk kehidupan bangsa dan bernegara, khususnya generasi muda. Dalam rangka membangun dan mempertahankan negara serta menumbuhkan rasa cinta terhadap tanah air, pendidikan kewarganegaraan bagi generasi muda sangatlah penting. Karena generasi muda adalah generasi penerus yang akan memimpin negara di masa kemudian hari.

Dalam pendidikan Pancasila dan kewarganegaraan, generasi muda memiliki kemampuan untuk meningkatkan kesadaran akan kebangsaan. Pemahaman dan peningkatan sikap dan perilaku yang berprinsip kriteria Pancasila dan kebiasaan bangsa merupakan hal terpenting pada pendidikan kewarganegaraan. Ini semua dalam rangka menumbuhkan wawasan dan kesadaran bangsa yan cinta terhadap tanah air, sikap dan perilaku, pandangan hidup, dan keuletan generasi muda bangsa.

Aspirasi utama Pancasila dan pendidikan kewarganegaraan untuk meningkatkan keilmuan nasional dan pengakuan diri serta perilaku berbangsa dan bernegara di kalangan generasi muda yang lagi belajar dan mendalami materi, kemajuan informasi, bahasa dan seni. Dan perilaku. Atas dasar pemahaman politik nasional dan fleksibilitas, mewujudkan warga negara yang memahami pertahanan negara untuk mengembangkan karakteristik dan perilaku masyarakat dalam kehidupan berbangsa. Selain itu, pendidikan Pancasila juga bertujuan agar masyarakat Indonesia menjadi warga negara yang berkelas, maju, tangguh, profesional, bertanggung jawab, dan produktif. Fungsi pendidikan kewarganegaraan adalah menumbuhkan landasan warga negara yang cerdas, terampil, dan perseorangan yang setia kepada negara dan negara Indonesia dengan mengubah pemikiran dan perilaku sesuai dengan informasi dalam Pancasila dan UUD 1945 (Depdiknas, 2001: 1).

Pada dasarnya Pancasila dan pendidikan kewarganegaraan merupakan cara sadar untuk mencerdaskan kehidupan masyarakat bagi warga negara dengan meningkatkan identitas diri bangsa serta perilaku berbangsa, sebagai cara untuk mewujudkan kekuasaan dan keharusan penyelamatan negara dan negara. Dasar kelanjutan hidup. Seiring dengan kemajuan zaman di era globalisasi saat ini, namun juga diiringi dengan perubahan yang pesat dan selalu dikelilingi oleh kehidupan yang bebas. Keadaan ini menyebabkan munculnya masalah-masalah baru yang semakin beragam dan terjadi di berbagai aspek kehidupan. Perkembangan teknologi informasi yang pesat telah berdampak pada kehidupan manusia. Jika bisa dimanfaatkan untuk meningkatkan taraf hidup / kesejahteraan sosial, ini mungkin berdampak positif. Pada saat yang sama, efek samping dapat ditipu jika digunakan untuk keuntungan negatif. Artinya, akibat kemajuan informasi berdampak langsung pada perubahan di segala segi kehidupan, termasuk perubahan kepribadian generasi muda yang cerdas. Kini, karakter generasi muda menjadi fokus perhatian sosial. Sorotan tersebut telah dimuat di media cetak, tanya jawab, percakapan atau dialog di sebagian media elektronik. Kasus-kasus yang timbul antara lain menambahnya kriminalitas, kolusi, korupsi dan nepotisme (KKN), kekejaman, kebrutalan, perkelahian massal, kehidupan 
konsumen, kehidupan politik tidak berlaku lagi, dan lain sebagainya. Kasus-kasus tersebut sering menjadi perbincangan hangat, dan Jangan pernah berhenti berdiskusi. Meskipun bangsa Indonesia telah merdeka lebih dari 50 tahun, namun karakter bangsa Indonesia sampai saat ini terus merosot.

Negeri ini, terutama generasi mudanya, menghadapi perkembangan dan perubahan lingkungan terjangkau yang kacau balau, rintangan kehidupan yang semakin meluas, serta turunnya nilai martabat bangsa membuat masalah ini semakin berwarna. Bahkan di Indonesia saat ini, pendidikan cenderung mengutamakan ilmu dan pengetahuan, dengan menepis pendidikan karakter. Pengetahuan mengenai aturan etika dari moralitas dan pendidikan moral sekarang secara bertahap ditinggalkan. Beberapa orang mulai berhenti memperhatikan bahwa pendidikan memengaruhi perilaku seseorang.

Untuk mengatasi permasalahan tersebut, pembangunan pendidikan karakter dibangun melalui pendidikan yang menyertakan seluruh pelosok tanah air, terutama pemangku kepentingan seperti Pendidikan Pancasila. Intinya, generasi muda tidak hanya mampu, tapi juga peduli dengan pemajuan Indonesia. Pendidikan pancasila dan kewarganegaraan sangat diperlukan untuk generasi selanjutnya di Indonesia untuk membentuk karakter yang cerdas. Dengan cara demikian akan tercipta generasi muda yang mampu menunjukkan akhlak, kesusilaan, kesopanan dan kesopanan dalam bermasyarakat, berbangsa dan bernegara. Dikarenakan karakter adalah tingkah laku atau akhlak manusia yang bersangkutan langsung dengan Tuhan YME, yang terwujud di antara manusia, antara lingkungan dan kebangsaan, dan tercermin dalam perasaan, pikiran, kepedulian, dan perilaku berdasarkan norma yang ada.

Generasi muda masa kini bisa menggambarkan masa depan Indonesia. Karakter, mentalitas, eksistensi, kemampuan dan peran generasi muda sangat menentukan arah masa depan negara. Keberadaan bangsa Indonesia di masa lalu sangat bergantung pada keahlian dan kekuatan kaum muda dalam menopang beban nasional. Inilah posisi strategis anak muda dalam sejarah negara. Oleh karena itu, masa depan bangsa Indonesia merupakan ciri khas anak muda masa kini. Mereka adalah nahkoda, yaitu negara Indonesia yang akan berlayar di lautan, mengangkut kapal dengan selamat selama pelayaran, atau mungkin sebaliknya menenggelamkan kapal karena menghantam "karang" globalisasi. Dalam proses modernisasi banyak generasi muda yang semakin impersonal, hal ini dikarenakan minimnya sekolah yang membekali siswa dengan pendidikan karakter dan moral, sehingga lahirlah generasi muda yang tidak berkarakter. Melihat hal tersebut, setiap sekolah kini memiliki misi membina anak bangsa yang berkarakter dan cerdas. Titik tolak kesuksesan suatu negara adalah kesuksesan generasi mudanya di masa depan, karena mempertahankan kesuksesan jauh lebih sulit daripada meraih kesuksesan itu sendiri.

Generasi muda adalah generasi penerus dari mereka yang mengubah estafet kepemimpinan.Mereka bekerja keras untuk mempertahankan misi ini.Ditemani dengan hal ini karena modal jasa mengalir ke seluruh dunia dan mempengaruhi penyatuan negara, persaingan di berbagai bidang juga semakin meningkat. Semakin intens, dan semua ini hanya bisa dicapai melalui daya saing yang berkualitas. Persaingannya sengit. Globalisasi adalah rancangan yang jumlahnya berfaedah dalam menghadapi keadaan bumi yang tidak ada pemisahnya. Salah satu fakta yang harus sering dianalisis dalam mengambil sikap globalisasi ialah perihal globalisasi yang mengiringi proses pergeseran terbukti telah mengikis atau malahan mematikan nilai kebijaksanaan ruang yang luas suatu kawasan. Dalam rangka mendirikan pendidikan karakter bangsa melewati pandangan hidup dan ilmu pengetahuan dan budaya, perlu dilakukan penelitian dan peningkatan karakter yang menitikberatkan pada penanaman pilar nilai-nilai kebangsawanan secara umum.

Pada hakikatnya pengembangan dan pembaharuan membutuhkan aplikasi iptek yang lebih tinggi, maka dari itu disamping persiapan mental serta kondisi fisik yang mapan, juga dibutuhkan talenta-talenta yang 
terampil, berkualitas dan berkarakter baik. Generasi muda harus benar-benar siap. Sebagai lembaga pendidikan informal, sekolah, perguruan tinggi dan universitas, serta pendidikan informal, merupakan wadah bagi generasi muda untuk mengembangkan diri. Oleh karena itu, generasi muda diharapkan dapat berperan aktif dalam mewujudkan kemandiriannya dan menunjukkan kesiapan yang baik sebagai peserta pembangunan nasional. Mampu bekerja dan berpikir rasional, demokratis, dan realistis, selalu mengabdikan diri kepada Tuhan Yang Maha Esa, mencintai tanah air, mencintai persatuan, bersatu padu untuk mewujudkan hari esok yang lebih baik.

Padahal, pendidikan karakter semacam ini sudah ada sejak lama lahirnya bangsa Indonesia. Para pendiri bangsa Indonesia memasukkannya ke dalam pembukaan Undang undang 1945 edisi kedua tahun 1954, dan membuat pernyataan yang jelas: " Bawa bangsa Indonesia menuju kemerdekaan, persatuan, dan kedaulatan, hanya pintu gerbang kemerdekaan bangsa Indonesia. Dan kemakmuran. Para penggagas negara memahami bahwa hanya dengan menjadi negara yang berdaulat, merdeka, adil dan makmur, bangsa Indonesia dapat dihargai dan dijunjung tinggi oleh negara lain. Sejak kemerdekaan Indonesia, pendidikan karakter sendiri telah dipikirkan oleh para ahli pembangun bangsa Indonesia, khususnya presiden pertama Ir. Soekarno mengadopsi pemikiran pembangunan karakter tentang Pancasila sebagai dasar negara dan ideologi negara, serta rintangan dan pengembangan pendidikan karakter di Indonesia. (Afandi, 2011, halaman 2) Pendidikan merupakan usaha ingin mengetahui dan teratur pada penumbuhan keterampilan berpikir murid. Karakter adalah karakter, akhlak, moralitas, yang terpenuhi sebagai hasil dari keyakinan terhadap sebagian kebajikan, yang dipertimbangkan dan diperlukan sebagai pendapat, pemikiran, perilaku, dan tindakan. Dapat juga dikatakan bahwa kepribadian disebabkan oleh kestabilan absolut dari ciriciri pribadi, yang menjadi dasar dari standar nilai atau norma yang tinggi. (Prayitno, 2010, hlm.38)
Menurut Durkheim, setiap pengajar harus mampu mewujudkan cita-cita moral yang ada dalam sistem aturan- aturan yang mapan dan memberikan kesempatan kepada generasi penerus untuk melengkapi syarat baru untuk efektifitas, artinya pemerintah harus lebih personal.Prinsip ini harus direkonstruksi oleh generasi baru manusia dengan mengembangkan setiap konsep moral hingga dapat dipromosikan. (Haricahyono, 1995, hlm.203)

Pendidikan moral adalah kegiatan yang membentuk moralitas masyarakat ke arah yang sesuai dengan tingkat kesiapannya, bukan hanya memaksakan bentuk eksternal di atasnya. Tugas guru adalah mengenalkan anak pada masalah konflik moral yang sebenarnya. Konsep moralitas meliputi ketaatan pada hukum moral, pengaruh aturan sosial, otonomi rasional dalam hubungan interpersonal dan otonomi kelangsungan hidup dalam pilihan. Pendidikan moral atau nilai dapat dikomunikasikan melalui teknologi langsung atau tidak langsung. Teknologi harus terlebih dahulu menentukan perilaku apa yang dianggap baik untuk menanamkan / mengajarkan berbagai ide. Dengan mempelajari, mendeskripsikan, mengingat, dan mengungkapkan asumsi ini secara cermat, dengan fokus langsung pada asumsi ini, teknik tidak dimulai secara langsung dengan menentukan perilaku baik mana yang dapat diterapkan.

Indoktrinasi / gagasan semacam ini melahirkan kemungkinan kemungkinan, pertama nilai-nilai yang diindoktrinasi ditanamkan, bahkan diingat oleh hati, tetapi tidak diinternalisasikan, apalagi diramalkan. Kemungkinan kedua, nilai-nilai ini digunakan pada kehidupan sehari-hari, tetapi ini bukan karena kesadaran diri, tetapi karena pengawasan kelas penguasa. Agar nilai pendidikan moral tidak universal, maka perlu dorongan untuk mencari alasan-alasan yang menjadi dasar pengambilan keputusan moral guna mengembangkan kemampuan pengendalian perilaku.

Permasalahan yang dialami dewan pendidikan adalah banyaknya norma yang bermunculan di masyarakat, jadi sulit untuk memutuskan norma mana yang akan 
diterapkan. Pendidikan moral harus fokus pada hubungan antara pemikiran moral dan perilaku moral. Tetapi juga harus diingat bahwa hanya melalui emosi dan kebijaksanaan spirituallah perilaku moral dapat konsisten dengan pemikiran moral.

Berdasarkan informasi yang diperoleh, keterampilan berpikir kritis generasi muda dibentuk melalui kegiatan pembelajaran, kemampuan seseorang agar menjadi anggota wilayah yang baik (good citizen) dan perilaku untuk mencapai perilaku karakter dalam lingkungan keluarga dilakukan upaya pembentukan karakter generasi cerdas. Masyarakat, bangsa dan negara. Pembelajaran yang baik mengacu pada partisipasi aktif dalam suatu kegiatan pembelajaran. Untuk mewujudkan karakter generasi yang pintar, setiap kelas harus secara aktif memungkinkan murid untuk memperdalam keterampilan berpikir kritisnya. Selain itu, sebagai pengajar harus mampu menjadi asisten pengajar siswa dan memenuhi semua yang diperlukan berlatih pelajar pada waktu pembelajaran terjadi. Sebagian peristiswa yang dikerjakan pengajar dalam menjadikan generasi pintar melewati aktivitas pembelajaran berbasis pengamatan dilakukan dengan: 1) merubah skema bimbingan kreatif, 2) menjadi fasilitator untuk membantu orang, dan 3) menanamkan nilai-nilai yang baik.

Bukan tugas yang mudah membangun peran generasi yang cerdas, karena sangat sulit membentuk model berpikir inovatif dan maju yang selalu menyertai peran yang baik. Masalah yang paling serius adalah peran pengajar sebagai acuan untuk mengembangkan nilai-nilai karakter sesuai dengan nilai karakter mata pelajaran dan nilai karakter secara publik. Cara kerja keras pembentukan karakter generasi muda cerdas adalah sebagai berikut: 1) Menumbuhkan kemampuan berpikir gawat melalui kegiatan belajar mengajar di ruangan; 2) Menumbuhkan kemampuan seseorang untuk menjadi warga negara yang baik, artinya individu telah menyadari kekuasaa dan keharusannya; 3) Mewujudkan perilaku karakter di lingkungan sekolah, keluarga, dan masyarakat.
Agar pembelajaran lebih bermanfaat, guru selalu meningkatkan proses pembelajaran. Tujuannya untuk memberikan berbagai proses agar siswa tetap tertarik dan termotivasi untuk belajar di dalam dan di luar ruangan. Tips yang bisa dilakukan dengan menggunakan berbagai metode pembelajaran. Proses pembelajaran adalah sejenis teknik mengajar, atau proses penyampaian dan kolaborasi antara pembimbing dan siswa untuk tuntutan pendidikan dan pengajaran. Belajar juga merupakan proses mengembangkan sikap dan sifat hakiki seseorang melalui bermacam-macam tahapan dan pengalaman. Proses pembelajaran dilakukan melalui berbagai teknologi dan multimedia, sebagai penjelasan dan analisis, ringkasan, pengembangan, evaluasi dan penguasaan (penggunaan, latihan / aplikasi) sebagai sarana dan prasarana untuk realisasi tujuan. Maka dari itu, dalam pembentukan karakter generasi pintar, guru begitu perlu berperan serta, mereka harus selalu aktif menanamkan nilai-nilai yang baik dalam setiap proses pembelajaran dengan memilih proses determinasi yang tepat, atau menjadi pendidik dan guru yang dapat mendidik murid.

Dalam survei ini ditemukan bahwa guru dan sekolah banyak menemui kendala dalam menumbuhkan kepribadian generasi yang cerdas. Pertanyaan yang bermasalah diantaranya:

1. Nilai karakter yang ditingkatkan sekolah belum ditransformasikan menjadi keterangan yang sesuai dengan fungsinya sehingga mengakibatkan kesulitan saat mengukur kinerja.

2. Sekolah tidak bisa memilih nilai karakter yang sesuai dengan tujuannya. Nilai kepribadian terlalu banyak, dan sulit bagi sekolah untuk memilih nilai kepribadian yang sesuai dengan tujuan / visi sekolah. Ini berdampak kecil pada pengembangan karakter.

3. Pemahaman pembimbing terhadap konsep pendidikan karakter masih kurang lengkap. Rencana pendidikan karakter belum didistribusikan dengan baik kepada semua guru. 
4. Guru tidak dapat menentukan nilai karakter sinkronisasi. Selanjutnya nilai-nilai kepribadian secara general, terdapat juga nilai-nilai kepribadian yang perlu dikembangkan pengajar dalam mata pelajaran. Selama proses pembelajaran, nilai karakter tema tidak dapat dieksplorasi dengan baik untuk dikembangkan.

5. pengajar belum ada kualifikasi yang memuaskan untuk menggabungkan nilai-nilai karakter ke dalam mata pelajaran yang mereka liput. Rencana sudah dilaksanakan, namun pelatihannya masih sangat berkurang, dengan adanya pendampingan guru dibatasi dalam memadukan nilai-nilai karakter mata pelajaran yang telah dipelajari.

6. Pengajar belum sanggup mencerminkan nilai karakter yang telah ditentukan. Kasus terpenting adalah posisi guru yang menjadi model untuk mewujudkan nilai-nilai karakter tertentu berdasarkan nilai karakter mata pelajaran dan nilai karakter umum.

\section{SIMPULAN}

Melalui penemuan dan pembicaraan penelitian yang sudah dibahas sebelumnya, dapat ditarik hasil akhir diantaranya adalah:

1. Dapat bekerja keras untuk membentuk karakter generasi yang cerdas dengan membentuk keterampilan berpikir kritis dan mengembangkan kemampuan seseorang untuk menjadi anggota negara yang baik (good citizen).

2. Peran Pancasila dan Guru PKn dalam membentuk peran generasi muda yang cerdas dapat menjadi fasilitator pembelajaran yang baik melalui penggunaan strategi pembelajaran yang tepat, serta mampu berada di lingkungan sekolah, keluarga atau masyarakat dalam sikap dan perilaku. Tanamkan nilai-nilai baik yang ingin dicapai. 3. Hambatan yang dihadapi pembimbing pada pembentukan kepribadian generasi pintar yaitu: 1) indeks nilai karakter yang terbentuk tidak pasti, 2) sekolah tidak menentukan nilai karakter yang cocok dengan tujuannya, 3) pemahaman pengajar terhadap konsep pendidikan karakter belum jelas jelasnya, 4) pembimbing bingung dalam memilih nilai karakter yang tepat saat memadahkan materi pembelajaran, 5) Kurangnya pelatihan untuk mengintegrasikan nilai karakter dalam belajar, 6) Tingkah laku pengajar yang belum seutuhnya menggambarkan nilai-nilai kemanusiaan di lingkungan sekolah.

\section{DAFTAR PUSTAKA}

Kusuma A, Doni. (2007). Pendidikan Generasi Karakter. Jakarta: Grasindo

Slideplayer-info.cdn.ampproject.org

www-rapendik-com.cdn.ampproject.org

sidaknews.com/detailpost/membangungenerasi-cerdas-dan-berkarakter-dikabupaten-pidie-jaya

trisinurat.blogspot.com/2017/11/pendidikankarakter-bagi-generasimuda.html?m=1 